\title{
GADOLINIUM SOLUBILITY AND VOLATILITY DURING DWPF PROCESSING
}

S. H. Reboul

January 2008

Process Science \& Engineering Section Savannah River National Laboratory Aiken, SC 29808

Prepared for the U.S. Department of Energy Under Contract Number DEAC09-96SR18500

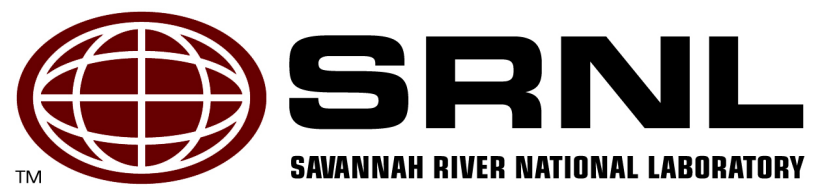




\section{DISCLAIMER}

This report was prepared by Washington Savannah River Company (WSRC) for the United States Department of Energy under Contract No. DE-AC09-96SR18500 and is an account of work performed under that contract. Neither the United States Department of Energy, nor WSRC, nor any of their employees makes any warranty, expressed or implied, or assumes any legal liability or responsibility for the accuracy, completeness, or usefulness, of any information, apparatus, or product or process disclosed herein or represents that its use will not infringe privately owned rights. Reference herein to any specific commercial product, process, or service by trademark, name, manufacturer or otherwise does not necessarily constitute or imply endorsement, recommendation, or favoring of same by WSRC or by the United States Government or any agency thereof. The views and opinions of the authors expressed herein do not necessarily state or reflect those of the United States Government or any agency thereof.

Printed in the United States of America

Prepared For

U.S. Department of Energy 
WSRC-STI-2008-00051

Revision 0

Key Words: Gadolinium

Solubility

Volatility

DWPF

Retention: Permanent

\section{GADOLINIUM SOLUBILITY AND VOLATILITY DURING DWPF PROCESSING}

S. H. Reboul

January 2008

Process Science \& Engineering Section Savannah River National Laboratory Aiken, SC 29808

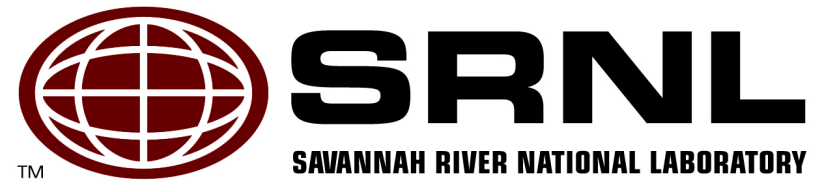




\section{REVIEWS AND APPROVALS}

\section{AUTHOR:}

S. H. Reboul, Process Engineering Technology

Date

\section{TECHNICAL REVIEWER:}

D. C. Koopman, Process Engineering Technology

Date

\section{APPROVERS:}

C. C. Herman, Manager, Process Engineering Technology

Date

R. E. Edwards, Manager, Process Science \& Engineering Section

Date

J. E. Occhipinti, Manager, Process Cognizant Engineering

Date

Waste Solidification Engineering 


\section{EXECUTIVE SUMMARY}

Understanding of gadolinium behavior, as it relates to potential neutron poisoning applications at the DWPF, has increased over the past several years as process specific data have been generated. Of primary importance are phenomena related to gadolinium solubility and volatility, which introduce the potential for gadolinium to be separated from fissile materials during Chemical Process Cell (CPC) and Melter operations.

Existing data indicate that gadolinium solubilities under moderately low $\mathrm{pH}$ conditions can vary over several orders of magnitude, depending on the quantities of other constituents that are present. With respect to sludge batching processes, the gadolinium solubility appears to be highly affected by iron. In cases where the mass ratio of Fe:Gd is 300 or more, the gadolinium solubility has been observed to be low, one milligram per liter or less. In contrast, when the ratio of Fe:Gd is 20 or less, the gadolinium solubility has been found to be relatively high, several thousands of milligrams per liter. For gadolinium to serve as an effective neutron poison in CPC operations, the solubility needs to be limited to approximately $100 \mathrm{mg} / \mathrm{L}$. Unfortunately, the Fe:Gd ratio that corresponds to this solubility limit has not been identified.

Existing data suggest gadolinium and plutonium are not volatile during melter operations. However, the data are subject to inherent uncertainties preventing definitive conclusions on this matter.

In order to determine if gadolinium offers a practical means of poisoning waste in DWPF operations, generation of additional data is recommended. This includes:

- Gd solubility testing under conditions where the Fe:Gd ratio varies from 50 to 150

- $\quad \mathrm{Gd}$ and $\mathrm{Pu}$ volatility studies tailored to quantifying high temperature partitioning

Additional tests focusing on crystal aging of $\mathrm{Gd} / \mathrm{Pu}$ precipitates should be pursued if receipt of gadolinium-poisoned waste into the Tank Farm becomes routine. 


\section{TABLE OF CONTENTS}

EXECUTIVE SUMMARY .......................................................................................III

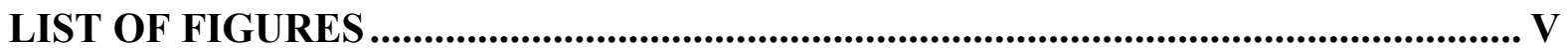

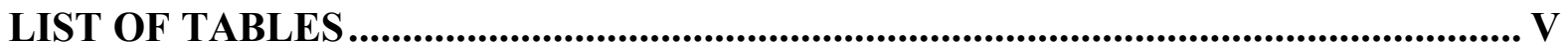

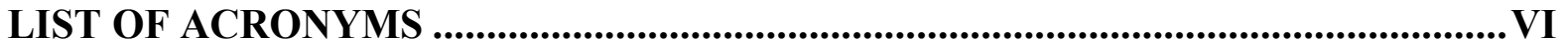

1.0 INTRODUCTION........................................................................................

2.0 OBJECTIVES ............................................................................................ 1

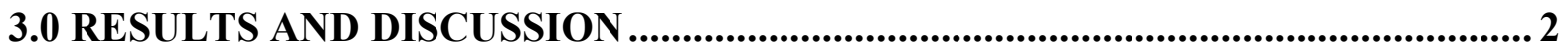

4.0 CONCLUSIONS ........................................................................................................ 12

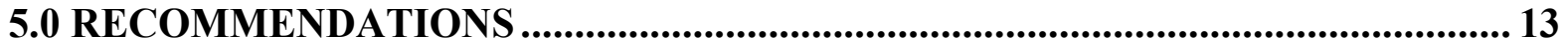

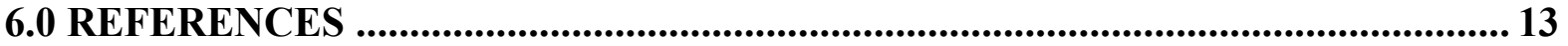


WSRC-STI-2008-00051

Revision 0

\section{LIST OF FIGURES}

Figure 1. Soluble Gd Concentration as a Function of $\mathrm{pH}$ as reported by Bronikowski and Visser.................5

Figure 2. Soluble Gd Concentration as a Function of $\mathrm{pH}$ as Reported by Bibler..............................

Figure 3. Soluble Gd Concentration as a Function of $\mathrm{pH}$ as Reported by Fellinger and Herman...................9

Figure 4. Soluble Gd Concentration as a Function of Fe:Gd Mass Ratio.......................................11

\section{LIST OF TABLES}

Table 1. Summary of Reports Addressing Gadolinium-Poisoning of SRS Waste 3 


\section{LIST OF ACRONYMS}

DWPF Defense Waste Processing Facility

FAVC Formic Acid Vent Condenser

NCSE Nuclear Criticality Safety Evaluation

SB3 Sludge Batch 3

SME Slurry Mix Evaporator

SMECT Slurry Mix Evaporator Condensate Tank

SRAT Sludge Receipt \& Adjustment Tank

SRS Savannah River Site

WSRC Washington Savannah River Company 


\subsection{INTRODUCTION}

Washington Savannah River Company (WSRC) is currently evaluating use of gadolinium as a supplemental neutron poison for future potential receipts of fissile material into the Defense Waste Processing Facility (DWPF). The primary advantage of using gadolinium over other neutron poisons is associated with gadolinium's high thermal neutron absorption cross section, which has the potential for significantly lowering poison demand. Because the quantity of poison has a direct impact on the number of glass canisters produced at DWPF, use of gadolinium offers a potential means for reducing the number of glass canisters produced in the future. However, the practicality of using such an approach has not been fully demonstrated and will require a clear understanding of gadolinium partitioning during processing in the Sludge Receipt \& Adjustment Tank (SRAT), the Slurry Mix Evaporator (SME), and the glass melter system. This understanding will be necessary to assure chemical conditions are sufficient to prevent segregation of gadolinium and fissile materials.

Over the past five years, several activities focusing on use of gadolinium as a neutron poison have been undertaken at WSRC. These activities have supported specific objectives, such as a) receiving additional fissile material into a DWPF sludge batch, b) adding relatively small quantities of gadolinium-poisoned fissile material to existing sludge waste stored in the Tank Farm, and c) possible dissolution of plutonium oxide material at H-Canyon. Now, with the expectation that several alternative fissile material streams may be dispositioned to DWPF, a more extensive evaluation of gadolinium as a neutron poison is warranted.

In this document, a literature search of gadolinium data pertaining to Savannah River Site (SRS) operations is addressed. The specific focus is gadolinium solubility during SRAT/SME processing and gadolinium/plutonium volatilization during the glass melting cycle. This literature search was performed at the request of the Waste Solidification Engineering group of the DWPF (Ray, 2007).

\subsection{OBJECTIVES}

1) Identify pertinent documentation addressing gadolinium solubility and volatility

2) Summarize $R \& D$ findings

3) Compile available data to illustrate data trends and gaps

4) Identify future studies that would be necessary to address data gaps 


\subsection{RESULTS AND DISCUSSION}

Twenty-one formal reports addressing gadolinium poisoning of Savannah River Site (SRS) waste were identified. A summary of the pertinent information in each of these documents is given in Table 1. Nine of the reports provide fundamental data on solid-liquid phase partitioning of gadolinium, plutonium, and uranium under chemical conditions applicable to SRS waste storage and disposition processes. This includes the reports authored by Bronikowski et al. (2002 and 2004), Fellinger et al. (2002), Bibler et al. (2002), Herman et al. (2002a and 2002b), and Visser et al. (2003a, 2003b, and 2005). Four reports provide information focusing on general processing impacts associated with adding gadolinium to waste. This includes the reports authored by Peeler et al. (2002), Smith (2002b), Fellinger et al. (2002), and Herman et al. (2002a). Three reports contain information addressing volatility of gadolinium and plutonium during the SRAT/SME cycle and in the DWPF melter system. These are the reports authored by Herman et al. (2002a) and Smith (2002a and 2002b). Four of the reports address formation of gadolinium fluoride solids during acid dissolution of plutonium oxide at $\mathrm{H}$-Canyon. These are the reports authored by Pierce et al. (2006, 2007a, 2007b, and 2007c). Five reports are Nuclear Criticality Safety Evaluations (NCSEs) which utilize the SRS data to draw conclusions regarding effective gadolinium poisoning.

Discussions of specific data applicable to gadolinium solubility during SRAT/SME processing and gadolinium/plutonium volatility during the SRAT/SME/melter cycle are presented below.

\subsection{Gadolinium Solubility at Negligible Fe:Gd Ratios}

Test reports authored by Bronikowski et al. (2002 and 2004) and Visser et al. (2003a, 2003b, and 2005) provide fundamental data focusing on solid-liquid phase partitioning of gadolinium and fissile materials under acidic, neutral, and alkaline conditions. These data were generated to support specific waste campaigns originating from $\mathrm{H}$-Canyon, under conditions where negligible iron was present to act as a neutron poison. For tests performed on actual canyon waste, the Fe:Gd mass ratio was nominally 0.10 , while for tests performed on simulated waste, the iron content was zero. Initial waste solutions were highly acidic and contained gadolinium concentrations ranging from 1700 to $5700 \mathrm{mg} / \mathrm{L}$, plutonium concentrations ranging from 0 to $3000 \mathrm{mg} / \mathrm{L}$, and uranium concentrations ranging from 0 to $5000 \mathrm{mg} / \mathrm{L}$. Solid-liquid phase partitioning was monitored as the $\mathrm{pH}$ of the waste was quickly raised to the following values: a) $3.0-4.5$; b) $~ 7$; and c) $\geq 14$. Results indicated that significant phase separation of the gadolinium and fissile materials occurred at $\mathrm{pH} 3.0-4.5$, where $70-90 \%$ of the gadolinium remained soluble, while $<10 \%$ of the plutonium and $<50 \%$ of the uranium remained soluble. In contrast, no significant phase separation occurred at the higher $\mathrm{pH}$ values $(\sim 7$ and $\geq 14)$, where $\leq 10 \%$ of the gadolinium, plutonium, and uranium remained soluble.

A plot of the soluble gadolinium concentrations as a function of $\mathrm{pH}$ (based on the Bronikowski and Visser data) is given in Figure 1. At pH 3.0 and 4.5, the concentrations range from a minimum of approximately $1000 \mathrm{mg} / \mathrm{L}$ to a maximum of approximately $5500 \mathrm{mg} / \mathrm{L}$. At pH 7 
Table 1 (Cont'd on Next Page). Summary of Reports Addressing Gadolinium-Poisoning of SRS Waste

\begin{tabular}{|c|c|c|}
\hline Document Number & Lead Author & Summary of Pertinent Information \\
\hline SRT-GPD-2002-00008 & M. E. Smith & - $\quad$ No segregation of Ce (Pu surrogate), Fe, and Mn detected in DWPF melter off-gas samples \\
\hline WSRC-TR-2002-00145 & D. K. Peeler & $\begin{array}{l}\text { - Addition of } 100 \mathrm{~kg} \mathrm{Pu} \text { and } 150 \mathrm{~kg} \text { Gd to SB3 will not impact glass quality, product performance, or } \\
\text { processability }\end{array}$ \\
\hline WSRC-TR-2002-00198 & M. G. Bronikowski & $\begin{array}{l}\text { - } \quad \text { Simulated waste contained no iron; } \mathrm{U}: \mathrm{Pu}=\sim 0.01 \\
\text { - } \\
\text { - }\end{array}$ \\
\hline WSRC-TR-2002-00199 & M. E. Smith & $\begin{array}{ll}\text { - } & \text { No Gd or Pu volatilization was observed during SRAT, SME, and melter cycles } \\
\text { - } & \text { Gd did not impact DWPF glass quality } \\
\text { - } & \text { More info needed on potential precipitation of Pu without Gd in SRAT }\end{array}$ \\
\hline WSRC-TR-2002-00208 & T. L. Fellinger & $\begin{array}{ll}\text { - } & \text { SB3 simulant with Fe: } \mathrm{Gd}=300 \\
\text { - } & \sim 1 \% \text { of } \mathrm{Gd} \text { was soluble and } 0.2 \% \mathrm{Pu} \text { was soluble during Tank Farm washing } \\
\text { - } & 3-5 \% \text { of } \mathrm{Gd} \text { was soluble and } \sim 0.2 \% \text { of } \mathrm{Pu} \text { was soluble during the SRAT cycle } \\
\end{array}$ \\
\hline N-NCS-H-00134, R1 & K. J. McCoid & $\begin{array}{l}\text { - } \\
\text { - } \\
\text { 1:1 mass ratio of } \mathrm{Gd}: \mathrm{Pu}-239 \text { equivalent is safe with } \mathrm{H}: \mathrm{Pu} \text { atomic ratio } \geq 30\end{array}$ \\
\hline WSRC-TR-2002-00211 & N. E. Bibler & $\begin{array}{l}\text { - } \quad \text { Tests performed in the absence of sludge (no iron) and with sludge (Fe: } \mathrm{Gd}=19) \\
\text { - } \quad \text { In absence of sludge at } \mathrm{pH} 3.5 \text {, all of } \mathrm{Gd} \text { was soluble, while only } 10 \% \text { of } \mathrm{Pu} \text { was soluble } \\
\text { - } \quad \text { With sludge at } \mathrm{pH} 3.5 \text { and } 4.0 \text {, about half of } \mathrm{Gd} \text { was soluble, while }<6 \% \text { of } \mathrm{Pu} \text { was soluble } \\
\text { - } \quad \text { With sludge at } \mathrm{pH} 6,13 \% \text { of Gd was soluble, while } 0.3 \% \text { of } \mathrm{Pu} \text { was soluble }\end{array}$ \\
\hline WSRC-TR-2002-00322 & C. C. Herman & 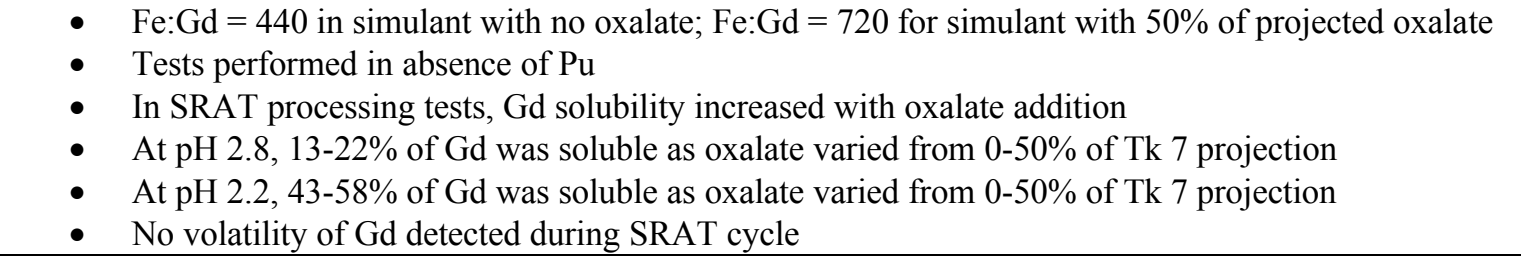 \\
\hline WSRC-TR-2002-00508 & C. C. Herman & $\begin{array}{l}\text { - } \mathrm{Fe}: \mathrm{Gd}=720 \text { for simulants with } 75 \% \text { and } 125 \% \text { of projected oxalate } \\
\text { - } \mathrm{Tests} \text { performed in absence of Pu } \\
\text { - } \\
\text { - } \\
\text { - } \\
\text { - }\end{array}$ \\
\hline
\end{tabular}


Table 1 (Cont'd from Previous Page). Summary of Reports Addressing Gadolinium-Poisoning of SRS Waste

\begin{tabular}{|c|c|c|}
\hline Document Number & Lead Author & Summary of Pertinent Information \\
\hline "WSRC-TR-2003-00193 & A. E. Visser & $\begin{array}{ll}\text { - } & \mathrm{Fe}: \mathrm{Gd}=0.1 \text { and } \mathrm{U}: \mathrm{Pu}=2.8 \\
\text { - } & \text { At pH } 4.5,91-94 \% \text { of } \mathrm{Gd} \text { was soluble, } 40-47 \% \text { of } \mathrm{U} \text { was soluble, and } 2-6 \% \text { of } \mathrm{Pu} \text { was soluble } \\
\text { - } & \text { At pH } 7, \text { up to } 1 \% \text { of } \mathrm{Gd} \text { was soluble, up to } 8 \% \text { of } \mathrm{U} \text { was soluble, and up to } 5 \% \text { of Pu was soluble } \\
\text { - } & \text { At pH } 14,<1 \% \text { of } \mathrm{Gd}, \mathrm{U} \text {, and Pu was soluble }\end{array}$ \\
\hline WSRC-MS-2003-00602 & A. E. Visser & - $\quad$ Version of WSRC-TR-2003-00193 prepared for Separation Science and Technology Conference \\
\hline WSRC-TR-2004-00053 & $\begin{array}{l}\text { M. G. } \\
\text { Bronikowski }\end{array}$ & $\begin{array}{l}\text { - } \quad \text { No iron; U:Pu:Gd ratio of 4.3:1:2.4 and } \mathrm{U}: \mathrm{Gd} \text { ratio of } 1: 1.1 \text { (no } \mathrm{Pu}) \\
\text { - }\end{array}$ \\
\hline N-NCS-H-00172, R1 & S. T. Gough & - $\quad$ NCSE for minimum safe Gd to fissile mass ratio in an infinite system (addresses uranium additions) \\
\hline WSRC-MS-2005-00008 & D. A. Eghbali & $\begin{array}{l}\text { - Discussion of how WSRC-TR-2002-00198, 00208, and } 00211 \text { were used to develop N-NCS-H- } \\
00134\end{array}$ \\
\hline N-NCS-H-00185 & L. M. Gundy & - $\quad$ NCSE for Gd neutron poison in solution with Pu solids present \\
\hline WSRC-MS-2005-00086 & A. E. Visser & $\begin{array}{ll} & \text { More data for } \mathrm{Fe}: \mathrm{Gd}=0.1 \text { and } \mathrm{U}: \mathrm{Pu}=2.8 \\
\text { - } & \text { At } \mathrm{pH} 4.5,94-97 \% \text { of } \mathrm{Gd} \text { was soluble, while } 8-47 \% \text { of } \mathrm{U} \text { was soluble and } 6-10 \% \text { of } \mathrm{Pu} \text { was soluble }\end{array}$ \\
\hline N-NCS-H-00179, R2 & L. A. Hedlund & - $\quad$ NCSE for receipt, transfer, storage, and neutralization of HB-line $\mathrm{Pu} / \mathrm{U}$ solutions poisoned with Gd \\
\hline WSRC-CP-2006-00001 & R. A. Pierce & $\begin{array}{l}\text { - } \text { Flowsheet for Pu-Be dissolution, addressing use of } \mathrm{Gd} \text { (instead of B) and } \mathrm{KF} \text { (instead of } \mathrm{CaF}_{2} \text { ) } \\
\text { - } \mathrm{GdF}_{3} \text { solids formed with } 4 \mathrm{M} \mathrm{HNO}_{3}, 4.5 \mathrm{~g} \mathrm{Gd} / \mathrm{L} \text {, and }>0.10 \mathrm{M} \mathrm{KF} \text { (no solids with } \leq 0.10 \mathrm{M} \mathrm{KF} \text { ) } \\
\text { - } \mathrm{No} \mathrm{solids} \mathrm{with} 4 \mathrm{M} \mathrm{HNO}_{3}, 2.2 \mathrm{~g} \mathrm{Pu} / \mathrm{L}, 0.22 \mathrm{~g} \mathrm{Be} / \mathrm{L}, 4.5 \mathrm{~g} \mathrm{Gd} / \mathrm{L}, 3.5 \mathrm{~g} \mathrm{Fe} / \mathrm{L} \text {, and } 0.05-0.15 \mathrm{M} \mathrm{KF} \\
\text { - } \quad \text { Recommendation to dissolve Pu-Be with } 4 \mathrm{M} \mathrm{HNO}_{3}, 4.5 \mathrm{~g} \mathrm{Gd} / \mathrm{L} \text {, and } 0.05 \mathrm{M} \mathrm{KF}\end{array}$ \\
\hline WSRC-ATS-2007-00048, R1 & R. A. Pierce & $\begin{array}{l}\text { - Application of } \mathrm{Pu}-\mathrm{Be} \text { dissolution flowsheet to enriched U-Pu materials case } \\
\text { - } \\
\text { - } \\
\text { Initial solution of } 4-6 \mathrm{M} \mathrm{HNO}_{3} \text { and } 0.05-0.10 \mathrm{M} \text { fluoride can be used with } 2 \mathrm{~g} \mathrm{Gd} / \mathrm{L} \\
\text { Uncertainty of whether } \mathrm{Gd} \text { will precipitate with } \mathrm{U} \text { and } \mathrm{Pu} \text { between } \mathrm{pH} 2 \text { and } 7\end{array}$ \\
\hline SRNL-ATS-2007-00082 & R. A. Pierce & $\begin{array}{l}\text { - } \text { Determination of whether Gd solids form when concentrating low assay Pu solutions to } 4 \mathrm{~g} / \mathrm{L} \\
\text { - } \quad \text { Unconcentrated solutions contain } 4-5 \mathrm{M} \mathrm{HNO}_{3}, 0.3-2.7 \mathrm{~g} \mathrm{Pu} / \mathrm{L} \text {, plus } \mathrm{Gd} \text { and } \mathrm{KF} \\
\text { - } \mathrm{No} \text { Gd solids formed when concentrating } \mathrm{HB}-\mathrm{Line} \text { enriched } \mathrm{U}-\mathrm{Pu} \text { solutions with minor impurities } \\
\text { - } \mathrm{Gd} \text { solids did form when concentrating } \mathrm{H}-\mathrm{Canyon} \mathrm{Pu}-\mathrm{Be} \text { and enriched U-Pu solutions }\end{array}$ \\
\hline WSRC-STI-2007-00673 & R. A. Pierce & 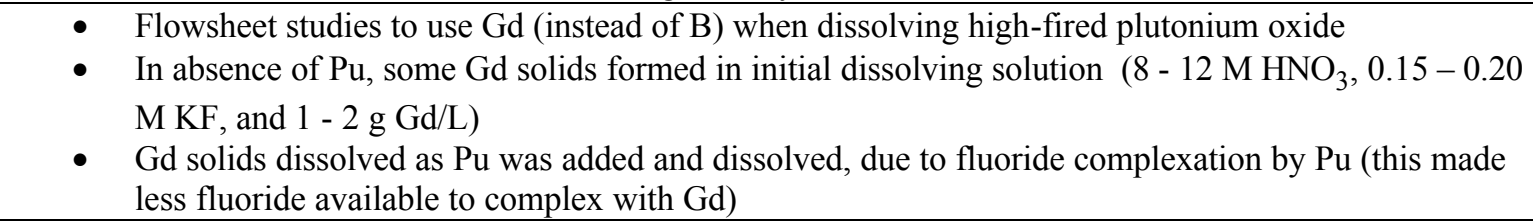 \\
\hline
\end{tabular}




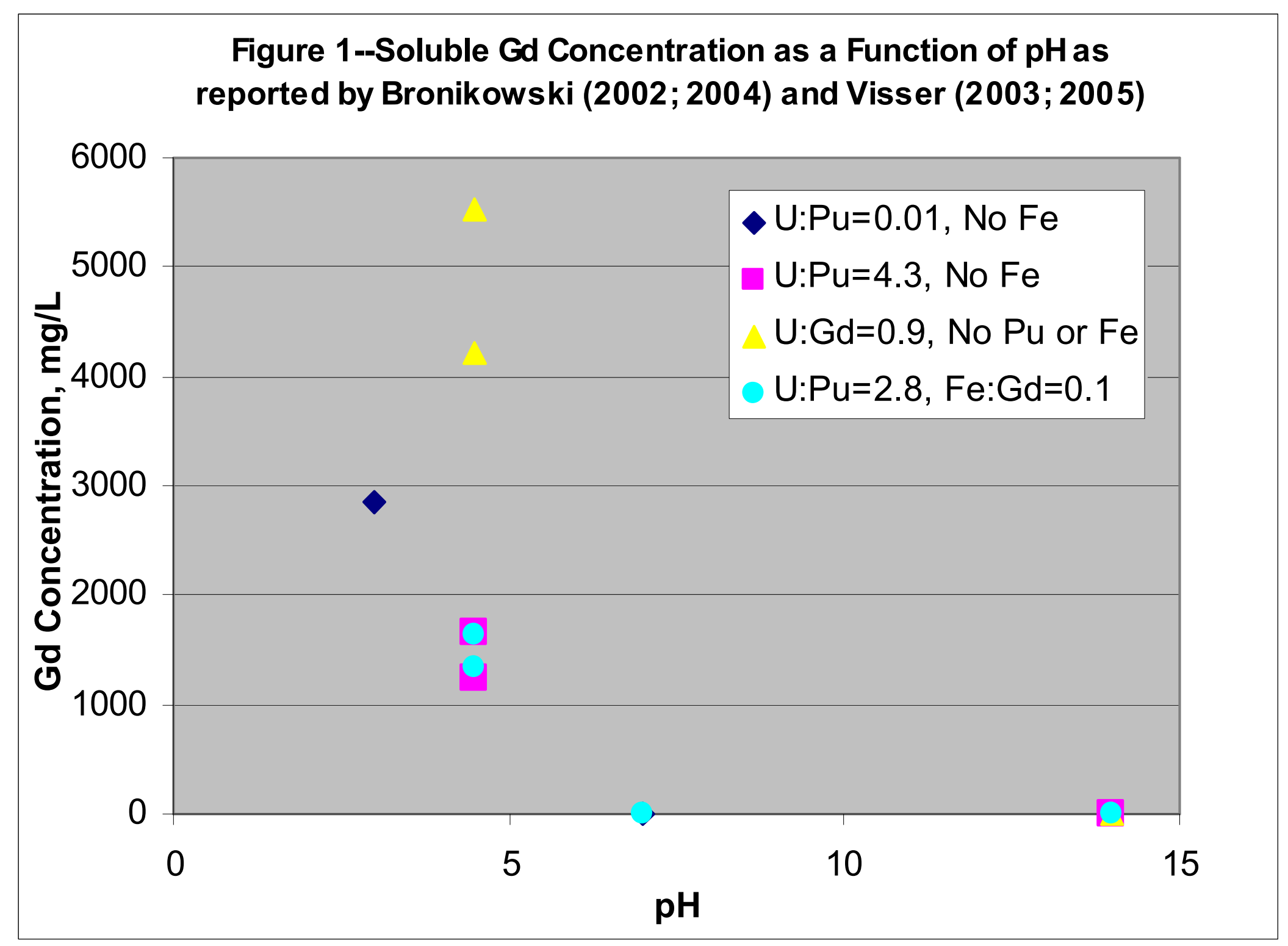


and 14, the concentrations are orders of magnitude lower, ranging from $<1 \mathrm{mg} / \mathrm{L}$ to a maximum of $6 \mathrm{mg} / \mathrm{L}$. These data are consistent with solids analyses, which show little or no detectable gadolinium in precipitates formed at $\mathrm{pH} 3.0$ and 4.5 , but clearly detectable gadolinium in precipitates formed at $\mathrm{pH} \sim 7$ and $\geq 14$. Analyses of solids formed at $\mathrm{pH} \sim 7$ and $\geq 14$ suggest that gadolinium and fissile materials are intimately mixed in the solids matrix. However, there is the possibility that aging of the solids will change the distribution of components when the solids become more crystalline. This potential aging effect is a concern for long term storage at the Tank Farm, not for the short term conditions of DWPF processing. To address this phenomenon, analyses of aged gadolinium/plutonium precipitates would be necessary.

\subsection{Gadolinium Solubility at Low Fe:Gd Ratios}

The test report authored by Bibler et al. (2002) provides data focusing on solid-liquid phase partitioning of gadolinium and plutonium under acidic conditions representative of the SRAT process. These data were generated to identify potential phase separation issues associated with adding gadolinium-poisoned plutonium to DWPF Sludge Batch 3 (SB3). The tests were performed in the absence and presence of a simulated sludge, at $\mathrm{pH}$ values of 3.5, 4.0, 4.5, and 6.0. In the presence of the simulated sludge, the Fe:Gd mass ratio was 19. Results indicated that phase separation of gadolinium and plutonium was significant at $\mathrm{pH} 3.5$ and 4.0, and moderate at $\mathrm{pH} 4.5$ and 6.0. In the absence of sludge at $\mathrm{pH} 3.5$, virtually all of the gadolinium was soluble, while only about $10 \%$ of the plutonium was soluble. In contrast, in the presence of sludge at $\mathrm{pH}$ 3.5 , about half of the gadolinium was soluble, while only $6 \%$ of the plutonium was soluble. At $\mathrm{pH} 4.0$ the gadolinium solubility was only marginally lower. However, at $\mathrm{pH} 4.5$ and 6.0, the solubilities were lower by factors of two and three, respectively.

A plot of the soluble gadolinium concentrations as a function of $\mathrm{pH}$ (based on the Bibler data) is given in Figure 2. At $\mathrm{pH} 3.5$, the gadolinium concentration was $\sim 2600 \mathrm{mg} / \mathrm{L}$ in the absence of sludge and $\sim 1500 \mathrm{mg} / \mathrm{L}$ in the presence of sludge. In contrast, at $\mathrm{pH} 4.5$ and 6.0 in the presence of sludge, the gadolinium concentrations were $\sim 700$ and $\sim 500 \mathrm{mg} / \mathrm{L}$, respectively.

Note that in the absence of sludge, all available gadolinium was soluble. This suggests that the true gadolinium solubility in the absence of sludge is likely $>2600 \mathrm{mg} / \mathrm{L}$. Although additional data would be required to reach definitive conclusions regarding this solubility in the absence of sludge, the data set as a whole suggests that presence of sludge reduces gadolinium solubility. Although sludge contains many components that could impact gadolinium solubility, it is likely that iron, because of its dominance, is a major driver. Discussion of this phenomenon will be continued below, after presentation of other pertinent data.

\subsection{Gadolinium Solubility at High Fe:Gd Conditions}

Test reports authored by Fellinger et al. (2002) and Herman et al. (2002a and 2002b) provide data on solid-liquid phase partitioning of gadolinium when added to DWPF SB3. The Fellinger data were generated using SB3 simulant mixed with precipitated $\mathrm{Gd} / \mathrm{Pu}$ material from $\mathrm{H}-\mathrm{Canyon}$ Tank 18.3. In contrast, the Herman data were generated using SB3 simulant mixed with laboratory-prepared gadolinium, and hence, did not contain plutonium. The Herman data were 


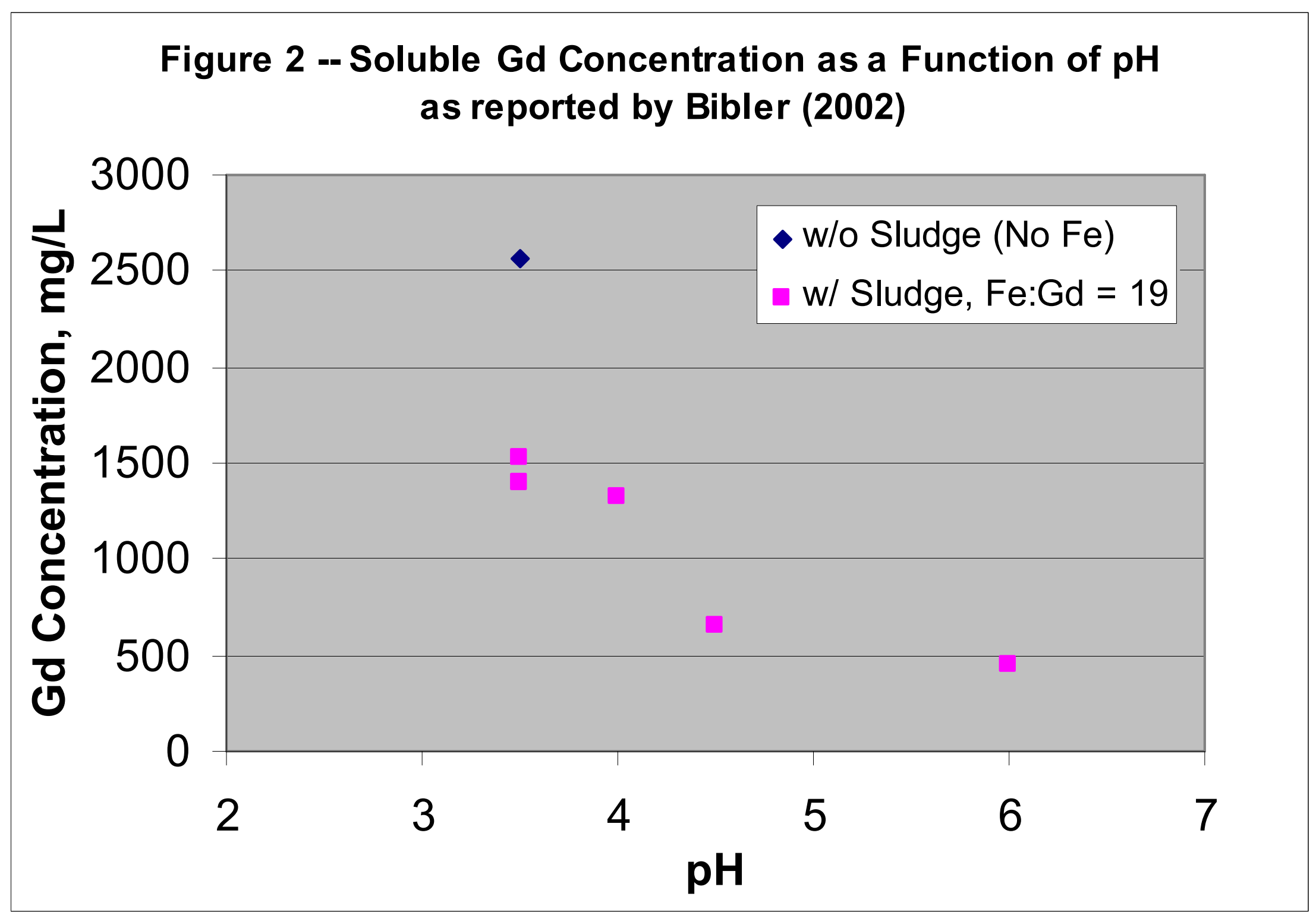


generated over a range of oxalate concentrations, spanning from 0 to $125 \%$ of the projected SB3 value. (In units of concentration, this range is 0 to $\sim 50,000 \mathrm{mg}$ oxalate per kilogram sludge (Herman et al., 2003)). The Fe:Gd mass ratio associated with the Fellinger testing was 300. The Fe:Gd mass ratio for the Herman testing was 440 in the absence of oxalate and 720 for tests performed when oxalate was present. The Fellinger data were collected at $\mathrm{pH}$ values of $\sim 3, \sim 4$, and $\sim 13$, while the Herman data were collected for three SRAT processing scenarios (normal and off-normal scenarios) with a collective $\mathrm{pH}$ span of 2 to 6 .

The Fellinger data suggested that minimal portions of the gadolinium and plutonium were soluble, regardless of whether the $\mathrm{pH}$ was 3,4 , or 12 . A maximum of $\sim 5 \%$ of the gadolinium and $\sim 0.2 \%$ of the plutonium was found to be soluble under the most acidic condition $(\mathrm{pH} \sim 3)$. Consequently, separation of gadolinium and plutonium was assumed to be insignificant.

In contrast, larger portions of the gadolinium were found to be soluble, based on the Herman data. In the absence of oxalate, almost half of the gadolinium was soluble at $\mathrm{pH} 2$, while about $10 \%$ of the gadolinium was soluble at $\mathrm{pH} 3$. In the presence of the highest oxalate concentrations ( $75 \%$ and $125 \%$ of the projection), the gadolinium solubilities were typically higher - up to $100 \%$ of the gadolinium was soluble at $\mathrm{pH} 2$, for example.

The disparity between the proportions of soluble gadolinium reported by Fellinger and Herman (low proportions in the Fellinger data and high proportions in the Herman data) is primarily due to the difference in quantities of gadolinium used in the respective tests. Significantly more gadolinium was used in the Fellinger tests, so the proportions that dissolved were commensurately lower. If significantly more gadolinium would have been used in the Herman tests, it is expected that the soluble portions would have been significantly lower.

A plot of the soluble gadolinium concentrations as a function of $\mathrm{pH}$ (based on the Fellinger and Herman data) is given in Figure 3. Between $\mathrm{pH} 2$ and 7, the gadolinium concentrations ranged from $<1 \mathrm{mg} / \mathrm{L}$ to $\sim 20 \mathrm{mg} / \mathrm{L}$. The highest gadolinium concentrations were seen at $\mathrm{pH} 2$ when $75 \%$ of the projected oxalate was present and at $\mathrm{pH} 3-4$ in the case where the Fe:Gd was 300. Also of note are the gadolinium concentrations occurring between $\mathrm{pH} 5$ and 7 in the case where $125 \%$ of the projected oxalate was present $(\sim 50,000 \mathrm{mg} / \mathrm{Kg}$ sludge $)$ - these Gd concentrations are relatively high $(\sim 10 \mathrm{mg} / \mathrm{L})$ and attributed to the increased complexation with oxalate that occurs in this $\mathrm{pH}$ regime.

Although some of the gadolinium concentrations given in Figure 3 may underestimate the true gadolinium solubilities (for the reason stated above), they are thought to be of the appropriate order of magnitude, since only a small portion of the data suggest complete dissolution of available gadolinium.

\subsection{Gadolinium Solubility as a Function of Fe:Gd Ratios}

As alluded to above, gadolinium solubilities under acidic conditions appear to be directly related to the quantity of iron that is present. This trend is demonstrated by the data applicable to the $\mathrm{pH}$ 2-6 regime - for Fe:Gd ratios of 0.1 or less, the solubility appears to be on the order of thousands 


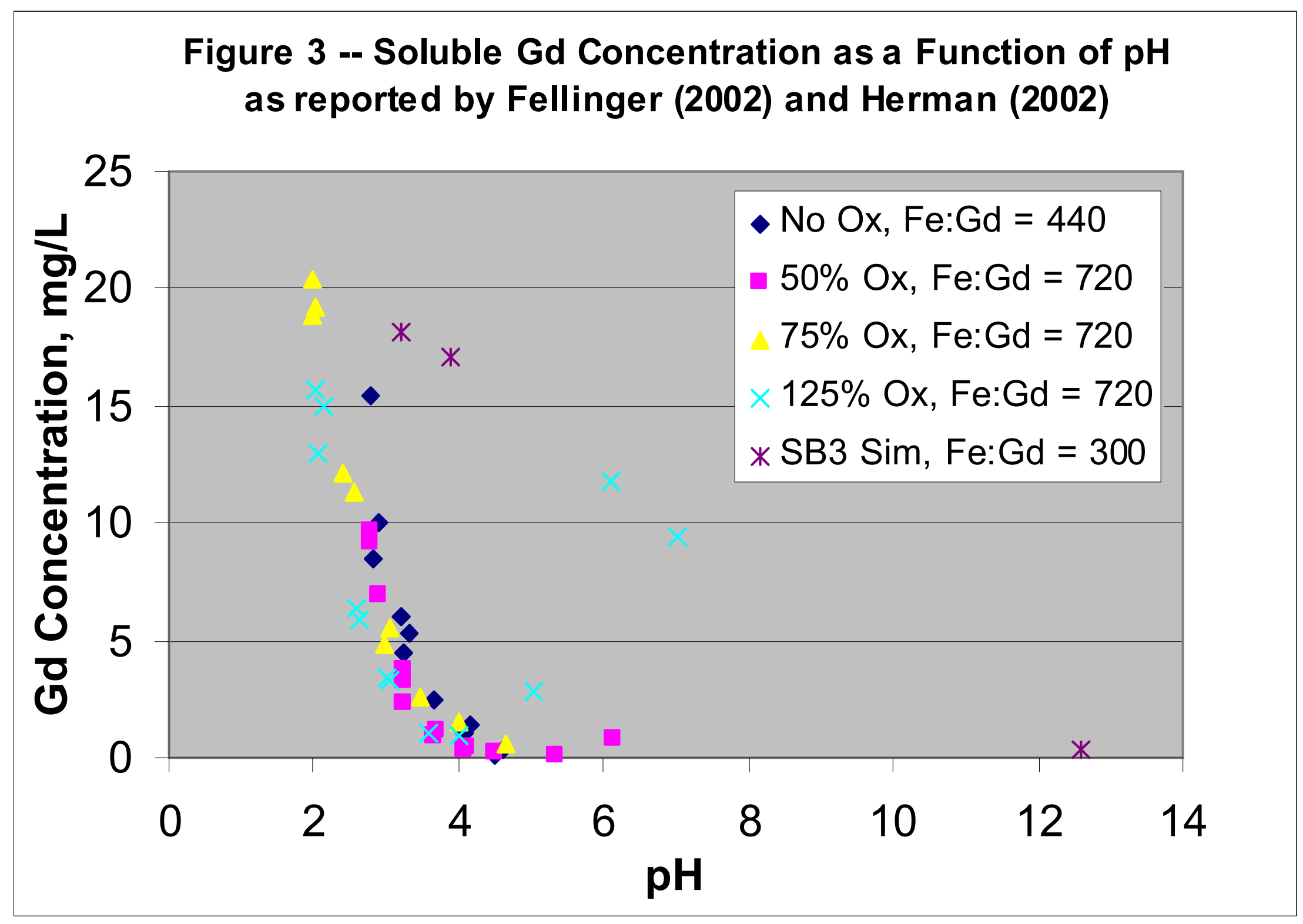


of $\mathrm{mg} / \mathrm{L}$; for Fe:Gd ratios of $\sim 20$, the solubility appears to be on the order of $1000 \mathrm{mg} / \mathrm{L}$; and for Fe:Gd ratios ranging from 300-720, the solubility appears to on the order of ten $\mathrm{mg} / \mathrm{L}$ or less. To illustrate this relationship, a plot of soluble gadolinium concentrations as a function of Fe:Gd ratio is given in Figure 4. Note that Figure 4 is based on the data that were previously presented in Figures 1, 2, and 3. However, Figure 4 only contains the data pertaining to the $\mathrm{pH} 2-6$ range and the data have been divided into two groups:1) data pertaining to the $\mathrm{pH}$ 2.0-4.0 range and 2) data pertaining to the $\mathrm{pH} 4.1-6.0$ range.

As shown in Figure 4, gadolinium solubilities decrease as the Fe:Gd ratio increases, and solubilities at $\mathrm{pH}$ 2-4 are typically somewhat higher than those at $\mathrm{pH} 4-6$, although not in every case. For the purposes of this evaluation, it is important to recognize that conditions must support a gadolinium solubility sufficiently low that the vast majority of the gadolinium will remain integrated in the solid phase with the fissile materials. If one assumes that the initial concentration of gadolinium is on the order of thousands of milligrams per liter, a maximum solubility on the order of $100 \mathrm{mg} / \mathrm{L}$ would likely be acceptable. However, as shown in Figure 4, the Fe:Gd ratio that corresponds to such a solubility $(\sim 100 \mathrm{mg} / \mathrm{L})$ is currently unknown, due to a lack of data.

A better understanding of the solubility behavior of gadolinium under conditions of moderate Fe:Gd ratios ( 100) and mildly acidic conditions will be necessary to draw sound conclusions about the practicality of using gadolinium poisoning in the SRAT/SME. Opportunities for obtaining additional data supporting this objective include analysis of current and near-term process samples (aluminum dissolution and sludge batch qualification samples, for example), as well as independent gadolinium/iron laboratory testing. The expectation is that effective use of gadolinium will require sufficient iron to depress the gadolinium solubility and sufficient gadolinium to assure effective neutron poisoning. Of course, if the Fe:Gd ratio requirement is so high that the iron alone provides adequate neutron poisoning, use of gadolinium will be unnecessary.

\subsection{Gadolinium and Plutonium Volatility}

Reports authored by Herman et al. (2002a) and Smith (2002a and 2002b) provide information pertaining to liquid-vapor phase partitioning of gadolinium and plutonium under elevated temperature conditions. This includes temperatures of around $100^{\circ} \mathrm{C}$ during SRAT/SME processing and around $1200^{\circ} \mathrm{C}$ during melter operations. The Herman document (2002a) addresses gadolinium volatility during SRAT/SME processing, based on gadolinium analyses of samples taken from the SRAT, the DWPF Slurry Mix Evaporator Condensate Tank (SMECT), and the Formic Acid Vent Condenser (FAVC). The primary conclusion was that gadolinium did not volatilize based on a) finding all of the original gadolinium in the SRAT product, and b) finding no detectable gadolinium in the SMECT and FAVC samples.

The first Smith document (2002a) contains analytical data from a pilot scale DWPF melter and plasma hearth test performed at the Argonne National Laboratory. Specifically, data are reported for cerium, which is considered an acceptable plutonium surrogate, and three dominant metals present in high level waste sludge (iron, manganese, and silicon). The primary conclusions were that there was no detectable separation of the plutonium surrogate (cerium) from the other metals 


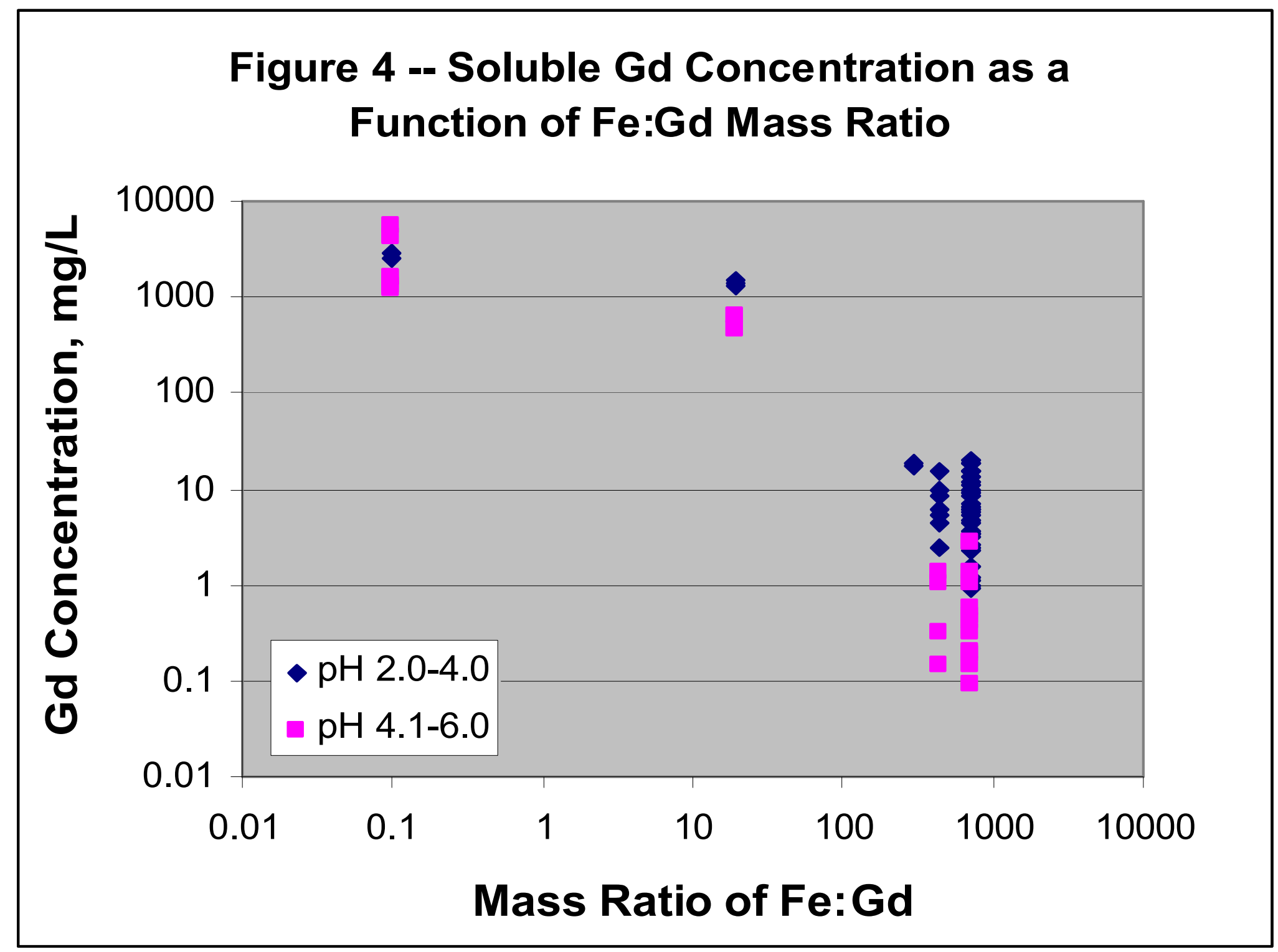


and that the metals were not volatile. The author identified the data in this report as being "somewhat limited."

The second Smith document (2002b) addresses gadolinium volatility based on neodymium data generated during waste qualification runs at DWPF. Neodymium was assumed to be an acceptable surrogate for gadolinium, based on similarity of chemical and physical properties. The primary conclusion was that neodymium did not volatilize, because almost all of the original neodymium was found in the final glass form (after SRAT, SME, and melter processing).

Findings of these three reports provide no basis for identifying either gadolinium or plutonium as being volatile. However, because the data are limited and/or based on surrogate behavior, the technical bases are not considered definitive. One concern is that the uncertainty of the data may mask losses due to volatility. Additional data based on high sensitivity analyses of gadolinium and plutonium (not $\mathrm{Gd}$ and Pu surrogates) in off-gas samples would strengthen the technical basis.

\subsection{CONCLUSIONS}

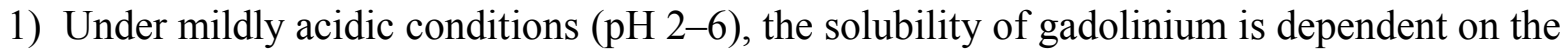
quantity of iron that is present. For Fe:Gd ratios $\leq 0.1$, the gadolinium solubility is on the order of thousands of $\mathrm{mg} / \mathrm{L}$. For Fe:Gd ratios $\approx 20$, the gadolinium solubility is on the order of 1000 $\mathrm{mg} / \mathrm{L}$. For Fe:Gd ratios ranging from $300-700$, the gadolinium solubility is typically $10 \mathrm{mg} / \mathrm{L}$ or less.

2) Effective use of gadolinium as a neutron poison requires a gadolinium solubility that is small, on the order of $100 \mathrm{mg} / \mathrm{L}$ or less for most applications. This can probably be achieved through control of the Fe:Gd ratio, although the minimum Fe:Gd ratio necessary to assure the solubility requirement is currently unknown. If the Fe:Gd ratio requirement is too high, the advantage of using gadolinium is defeated. However, if the Fe:Gd ratio requirement is sufficiently low (on the order of 100 or less), use of gadolinium may prove practical.

3) Low $\mathrm{pH}$ gadolinium solubility data at $\mathrm{Fe}$ Gd ratios between 20 and 300 will facilitate assessment of gadolinium poisoning practicality. In the absence of such data, a clear conclusion regarding practicality can not be drawn.

4) High concentrations of oxalate increase the gadolinium solubility at $\mathrm{pH}$ conditions typical of the normal SRAT cycle. This effect needs to be acknowledged when considering gadolinium poisoning of wastes with high oxalate content.

5) No evidence exists to support volatilization of gadolinium and plutonium during SRAT, SME, and glass melter cycles. However, the data that have been reviewed are limited and/or based on observations of surrogate materials that may not be representative. Additional data would provide a stronger basis for defining volatility behavior. 
6) Understanding of $\mathrm{Gd} / \mathrm{Pu} / \mathrm{U}$ precipitate aging will become important if neutralized $\mathrm{Gd}$ poisoned waste is stored for extended periods of time (such as is possible if acceptance of Gdpoisoned waste into the Tank Farm becomes routine). Existing data on Gd-containing precipitates are limited to fresh solids, in which Gd and fissile materials appear to be evenly distributed. A potential concern with aged solids is that crystallization effects could cause segregation of Gd and fissile materials. Although such effects are not directly related to SRAT/SME processing, they are pertinent to sludge awaiting disposition at DWPF and should be recognized.

\subsection{RECOMMENDATIONS}

1) Perform low $\mathrm{pH}$ gadolinium solubility tests under conditions of Fe:Gd ratios between 20 and 300. The goals of these tests would be a) to provide confirmation that gadolinium solubility is a function of the Fe:Gd ratio, and b) to identify the minimum Fe:Gd ratio needed to limit the gadolinium solubility to an acceptable level. Suggested conditions for the tests are:

- Sufficient gadolinium present to assure $<100 \%$ dissolution

- Fe:Gd ratios of 50, 100, and 150

- Soluble Gd and Fe concentrations measured over the $\mathrm{pH}$ 2-7 range

- Two $\mathrm{pH}$ adjustment strategies - one where $\mathrm{pH}$ is adjusted after $\mathrm{Gd}$ and $\mathrm{Fe}$ are combined, and one where $\mathrm{pH}$ is adjusted prior to combining $\mathrm{Gd}$ and $\mathrm{Fe}$

- With and without oxalate, as appropriate

2) To strengthen the technical bases for defining $\mathrm{Gd} / \mathrm{Pu}$ volatility behavior during $\mathrm{DWPF}$ processing, perform a) a detailed analysis, including assessment of data uncertainty impacts, of all existing process data relevant to $\mathrm{Gd} / \mathrm{Pu}$ volatility; b) volatility tests designed for the specific purpose of quantifying $\mathrm{Gd} / \mathrm{Pu}$ volatility during DWPF processing; and/or c) new DWPF process sampling and analysis tailored to quantifying $\mathrm{Gd} / \mathrm{Pu}$ volatility.

3) If gadolinium-poisoning is expected to become routine and dominate over traditional poisoning practices, perform $\mathrm{Gd} / \mathrm{Pu} / \mathrm{U}$ precipitate aging tests to determine if gadolinium and fissile materials in hydroxide precipitate crystals will segregate over time. Although not a specific SRAT/SME processing concern, the effect of precipitate aging is a concern relevant to sludge storage at the Tank Farm (prior to transferring the waste to DWPF).

\subsection{REFERENCES}

Bibler, N. E., M. G. Bronikowski, J. H. Gray, and B. C. Hill, "Behavior of Pu and Gd Mixtures Under Simulated SRAT Conditions,” WSRC-TR-2002-00211, Rev. 0, May 13, 2002.

Bronikowski, M. G., J. H. Gray, B. C. Hill, F. R. Graham, and D. G. Karraker, "Caustic Precipitation of Plutonium using Gadolinium as the Neutron Poison for Disposition to High Level Waste," WSRC-TR-2002-00198, May 3, 2002. 
Bronikowski, M. G. and T. S. Rudisill, "Neutralization of Plutonium and Enriched Uranium Solutions Containing Gadolinium as a Neutron Poison," WSRC-TR-2004-00053, Rev. 0, February 2004.

Eghbali, D. A. and K. J. McCoid, "Use of Gadolinium as a Primary Criticality Control in Disposing Waste Containing Plutonium at SRS,” WSRC-MS-2005-00008, January 2005.

Fellinger, T. L., D. T. Hobbs, M. G. Bronikowski, B. C. Hill, and J. H. Gray, "Demonstration of the Tank Farm Washing Process and the DWPF SRAT Cycle with Sludge Batch 3 Simulant and Precipitated Pu/Gd Mixture from H-Canyon Tank 18.3," WSRC-TR-200200208, May 8, 2002.

Gough, S. T., "Nuclear Criticality Safety Evaluation: Minimum Safe Gadolinium to Fissile Mass Ratio in an Infinite System,” N-NCS-H-00172, Rev. 1, November 11, 2004.

Gundy, L. M., "Nuclear Criticality Safety Evaluation: Gadolinium Neutron Poison in Solution with Plutonium Solids Present," N-NCS-H-00185, March 15, 2005.

Hedlund, L. A., "Nuclear Criticality Safety Evaluation: Double Contingency for Receipt, Transfer, Storage, and Neutralization of HB-Line Plutonium/Uranium Solutions Poisoned with Gadolinium," N-NCS-H-00179, Rev. 2, September 25, 2007.

Herman, C. C., D. C. Koopman, N. E. Bibler, D. R. Best, and M. F. Williams, "SRAT Processing of Sludge Batch 3 Simulant to Evaluate Impacts of H-Canyon Slurry Containing Precipitated Pu and Gd," WSRC-TR-2002-00322, Rev. 0, July 25, $2002 \mathrm{a}$.

Herman , C. C. and D. R. Best, "Supplemental Solubility Data for SRAT Processing of Sludge Batch 3 with H-Canyon Slurry Containing Precipitated Pu and Gd in DWPF," WSRC-TR-200200508, Rev. 0, November 15, 2002 b.

Herman, C. C., D. C. Koopman, D. R. Best, and M. F. Williams, "Data Summary from SRAT Runs SB3-19 to SB3-24 to Evaluate Sodium Oxalate Addition Levels and SME Processing," SRT-GPD-2002-00200, January 27, 2003.

McCoid, K. J., "Nuclear Criticality Safety Evaluation: Minimum Safe Gadolinium to Plutonium Ratio in an Infinite System,” N-NCS-H-00134, Rev. 1, July 12, 2002.

Peeler, D. K., N. E. Bibler, and T. B. Edwards, "An Assessment of the Impacts of Adding $\mathrm{Am} / \mathrm{Cm}$ and $\mathrm{Pu} / \mathrm{Gd}$ Waste Streams to Sludge Batch 3 on DWPF $\mathrm{H}_{2}$ Generation Rates and Glass Properties," WSRC-TR-2002-00145, Rev. 0, March 22, 2002.

Pierce, R. A., R. P. Campbell-Kelly, and M. G. Bronikowski, "Complexation of Fluoride by Boron and Gadolinium in H-Canyon Dissolution Flowsheets," WSRC-CP-2006-00001, May 2006.

Pierce, R. A., "Dissolution of EU-Pu Materials in H-Canyon," WSRC-ATS-2007-00048, Rev. 1, August 21, 2007a. 
Pierce, R. A. and N. J. Bridges, "In-Tank Concentration of Low Assay Pu Solutions," SRNLATS-2007-00082, November 30, 2007b.

Pierce, R. A., J. H. Gray, and M. G. Bronikowski, "Flowsheet Studies for the Dissolution of High-fired Plutonium Dioxide in the Presence of Gadolinium," WSRC-STI-2007-00673, December 2007c.

Ray, J. W., "Review of Gadolinium Solubility and Volatility during DWPF Processing," Technical Task Request, HLW-DWPF-TTR-2008-0003, Rev. 0, November 5, 2007.

Smith, M. E., "Fate of Plutonium in DWPF Melter Off-gas System," SRT-GPD-2002-00008, January 23, 2002a.

Smith, M. E., "Impact Analysis - Impact of Adding H-Canyon Stored Plutonium in Sludge Batch 3," WSRC-TR-2002-00199, April 30, 2002 b.

Visser, A. E., T. S. Rudisill, and M. G. Bronikowski, "Investigation of Plutonium and Uranium Precipitation Behavior with Gadolinium as a Neutron Poison," WSRC-TR-2003-00193, May 2003a.

Visser, A. E., T. S. Rudisill, and M. G. Bronikowski, "Investigation of Plutonium and Uranium Precipitation Behavior with Gadolinium as a Neutron Poison," WSRC-MS-2003-00602, Rev. 0, October 2003 b.

Visser, A. E., M. G. Bronikowski, and T. S. Rudisill, "Caustic Precipitation of Plutonium and Uranium with Gadolinium as a Neutron Poison," WSRC-MS-2005-00086, Rev. 0, April 2005. 


\section{Distribution:}

L. M. Abney, WSMS

B. J. Adkins, 766-H

A. L. Barnes, 999-W

N. E. Bibler, 773-A

P. L. Bovan, 704-27S

M. G. Bronikowski, 773-A

S. D. Burke, 704-S

D. B. Burns, 786-5A

D. A. Crowley, 999-W

C. E. Duffey, 703-H

R. E. Edwards, 773-A

D. A. Eghbali, 992-3W

H. H. Elder, 704-26S

T. L. Fellinger, 704-26S

K. D. Gilbreath, 766-H

J. M. Gillam, 766-H

B. A. Hamm, 766-H

J. R. Harbour, 999-W

C. C. Herman, 773-42A

J. F. Iaukea, 704-30S

C.M. Jantzen, 773-A

M. T. Keefer, 766-H

D. C. Koopman, 999-W

C. A. Langton, 773-43A

T. T. Le, 703-H

J. M. Low, 992-3W

D. J. Martin, 703-H

R. T. McNew, 704-27S

J. E. Occhipinti, 704-S

S. G. Phillips, 704-15S

J. W. Ray, 704-S

R. L. Reed, 992-3W

H. B. Shah, 766-H

M.E. Smith, 999-W

K. R. Yates, 730-4B 